\title{
Changes in the life strategy and adaptation of the reproductive strategy of Carex digitata to disturbances factors
}

\author{
Grażyna Laska
}

Department of Environmental Protection and Management, Białystok Technical University, Wiejska 45a, 15-351 Białystok, Poland

e-mail: g.laska@pb.edu.pl

\begin{abstract}
The aim of the paper was to define a relationship between the structure and dynamics of the Carex digitata population. Additionally, modifications in the development of an individual and its life strategy in disturbed communities were analysed. The species was studied in the natural and anthropogenically disturbed oak-hornbeam communities over 23-years of research (1987-2009) conducted on permanent plots in the Knyszyńska Forest. The results of the research indicate that in the natural community, $C$. digitata individuals reach the phase of flowering and fruition in the $4^{\text {th }}$ year of the life cycle, while in the disturbed community dominated by pine trees - in the $2^{\text {nd }}$ year of the life cycle. Modification of the $C$. digitata life cycle can be attributed to different reactions of individuals to disturbances in the community, microclimatic, phenological and biocenotic balance to which $C$. digitata is exposed as a results of the degeneration (pinetization) of the community. The sedge responds differently to specific ecological conditions in the natural and anthropogenically disturbed oak-hornbeam communities due to different life strategies, which affect morphological and developmental features of individual plants, and thus induces changes in the structure and dynamics of populations. This is reflected in a different spatial organization, age structure, size diversity of the individual plants, as well as in various mechanisms regulating the number of individual plants in a population.
\end{abstract}

Key words: life-history strategies, Carex digitata, long-term study, demography, disturbance.

\section{Introduction}

The study of population variation in time and space should take into account the evolutionary (life history), genetic (genetic structure), morphological (growth types) and ecological (environmental) aspects (Stearns 1992; Chapin et al. 1993; Yong 1995; Grime 2001; Tayler et al. 2002; Willis \& McElwain 2002; Loeuille \& Leibold 2008; Bornhofen et al. 2011). The structure and dynamics of plant populations are determined by the life-history traits of each species in conjunction with environmental heterogeneity and disturbances (Pickett et al. 1989; Poschlod et al. 2000; Falster
\& Westoby 2003; Pueyo et al. 2010). Individual traits and their variation provide a criterion for distinguishing various life strategies among plants (Ramenskii 1938; MacArthur \& Wilson 1967; Pianka 1970; Grime 1979, 1987, 1988, 2001; Stearns 1992; Westoby et al. 2002; Mustard et al. 2003). According to Grime (1979) strategies may be defined as groupings of similar or analogous genetic characteristics which vary widely among species or populations and cause them to exhibit similarities in ecology. The C-S-R strategy theory (Grime 1979) treats disturbances, as well as stress and competition, as the phenomena which can produce changes in the strategy of life of species taki- 
ng place in response to varying environmental conditions. Plant's response to disturbance is revealed in variation of life history traits, e.g. life span, reproductive efficiency, number of progeny and matter allocation, morphological and developmental properties and ability to survive in adverse conditions (Laska 1996a, b, 1998, 2001, 2003; Craine et al. 2001; Grime 2001; Lehsten \& Kleyer 2007). Disturbances determine to a significant degree which biological features of individuals and which particular types of life strategy will be preferred at a given site and will ensure successful reproduction. The response of species to disturbances becomes then the criterion of division into particular biological types able to adapt to different external interactions. Stearns (1992) suggests that "strategy" is a complex adaptation and describes a co-ordinated evolution of all life history traits combined. The adaptation of plants to environmental conditions is mainly to increase their fitness (Yong 1995). The measure of fitness of individuals in environmental conditions is their survival till the age of reproduction and production of offspring, i.e. characteristics which affect the demographical processes, and thereby, the population dynamics.

The present paper is an attempt to demonstrate the most significant individual and population interrelations of Carex digitata in natural and anthropogenically disturbed oak-hornbeam communities in the Knyszyńska Forest. The aim of this study is to find interrelations between the structure and dynamics of the $C$. digitata population and the modifications in the development of an individual and its life strategy in disturbed communities. In this way it has been established how a single population responds to disturbances and whether the plasticity of $C$. digitata individuals allows them to adapt to disturbed communities.

\section{Species study}

The study of Carex digitata L. (Cyperaceae) in natural and disturbed oak-hornbeam communities on the territory of the Knyszyńska Forest has been conducted since 1987. The species is a good object for analyses. Although it is treated as a mesotrophic oak-hornbeam species, growing most often in the shady deciduous forests (Matuszkiewicz 2001; Zarzycki et al. 2002), it also occurs in other habitat diversified natural communities (in mixed deciduous and coniferous forests) and in the anthropogenically disturbed communities (on the clear-cuts, in pine cultivations, in the secondary forest communities with an artificial pine stand) (Laska 2006).

C. digitata grows in the temperate zone of Europe and Asia, mostly on plain territories and in mountainous regions (Tayler et al. 2002). It grows in tussocks of 10 to $30 \mathrm{~cm}$ high. The tussock, a typical form of an adult individual, consists of a complex system of shoots with nu-

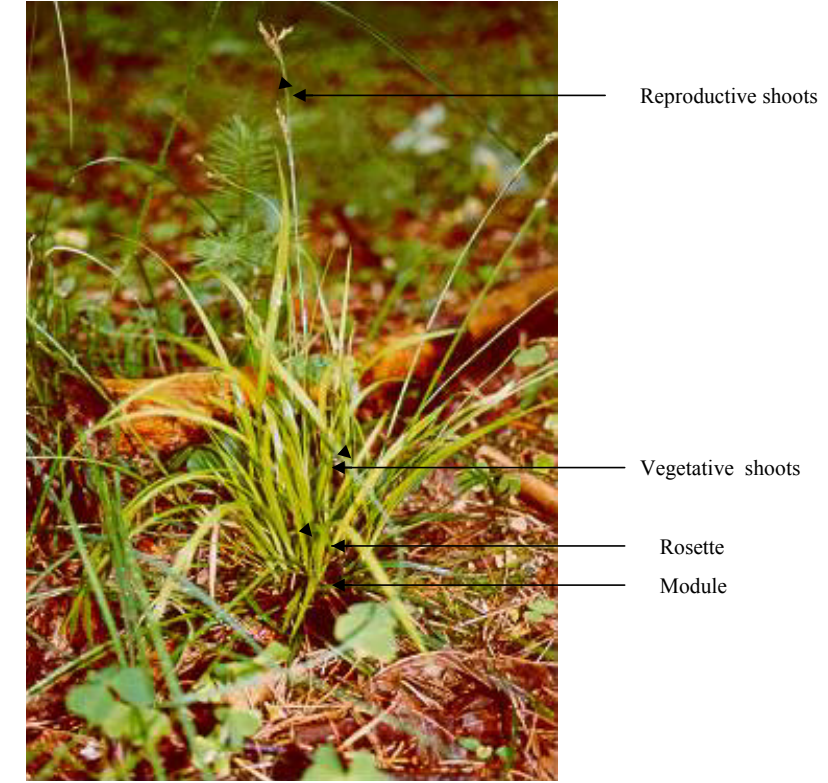

Figure 1. Morphological units of a tussock (an individual) of Carex digitata $\mathrm{L}$.

Module - major element of the tussock, taking root. Tussock division into modules is clearly defined in the underground part of plant. A modules is composed of a varying number of rosettes; Rosette - a secondary unit of the tussock, without roots, but participating in the further branching of modules. Module division into rosettes is visible in the aerial part of the plant. A rosette is composed of a number of shoots; Shoots - occur in two forms - vegetative and reproductive.

merous branches, modules, rosettes and shoots making up its morphological structure (Fig. 1). C. digitata is a paroecious (i.e. with separate male and female inflorescences on the same individuals) longlived perennial sedge. As a stem perennial plant (caulophyte) it produces new shoots of 3 to 5 year durability each year. The shoots of intravaginal origin have a monopodial type of branching (Fomićeva 1977). As a biological type (life-form) C. digitata is classified as a hemicryptophyte and a rosette monopodial plant (Zarzycki et al. 2002). Ellenberg (1974) defines its structure as mesomorphic or scleromorphic. C. digitata flowers in April and May. The flowers are wind-pollinated. The fruit is in the form of little nuts hidden in sacs. Seeds are dispersed by ants (myrmekochoria). Germination of seeds takes place underground (hypogeously) (Nowikov 1967).

\section{Study site}

The population of $C$. digitata was studied in the Knyszyńska Forest. This is a woodland area of about $1267 \mathrm{~km}^{2}$, located in the NE Poland between lat. $52^{\circ} 55^{\prime}$ and $53^{\circ} 42^{\prime} \mathrm{N}$, and long. $22^{\circ} 52^{\prime}$ and $23^{\circ} 54^{\prime}$ E. The study concerned com- 
munities representing one type of oak-hornbeam forest Tilio cordatae-Carpinetum betuli Tracz. 1962. Observations were made in natural and secondary forest communities. The natural community with no visible man-induced deformation was taken as model of standard phytocoenosis. The secondary forest community was treated differently, as anthropogenically disturbed by the process of pinetization (Łaska 1997, 2004, 2006). In this process 90 years ago the natural oak-hornbeam forest used clear-cutting and artificial reforestation pine (Pinus sylvestris) and now, it is a 90 -years old secondary forest community with pine stand domination.

\section{Methods}

\subsection{Diversity of individuals}

The study was carried out from 1987 to 2009 ( 23 years) on two permanent plots of $500 \mathrm{~m}^{2}$ each. The diversity of the individual features of the sedge was defined on the basis of the life cycle, morphology of tussocks and generative reproduction. During field observation attention was paid to permanently marked individuals, were classified into an ontogenetic series - from seedlings to senile individuals. Biological age was determined. Thus the life cycle of $C$. digitata and the modifications resulting from the plant's occurrence in different types of communities were determined. The diversity in the structure of individual plants in each population was described through different features characterizing each individual (height of shoots, diameter of tussocks, number of modules and rosettes). The germinating capacity and survival of seedlings were studied during field experiment, and the fertility and the ability of seeds to germinate was defined under laboratory conditions (Łaska 1996a).

\subsection{Diversity of the population}

The diversity of the population of $C$. digitata was defined using the structural dynamics, age structure, size of individual plants and the dynamics in the number of populations as a basis. The material was described by means of field, statistical and graphical methods.

In order to evaluate the spatial structure of populations of $C$. digitata, the area of $500 \mathrm{~m}^{2}(10 \times 50 \mathrm{~m})$ was divided into smaller plots $\left(1 \mathrm{~m}^{2}\right)$ and sedge individuals were mapped. Plans of tussock distributions were prepared on a scale $1: 100$. Thus, on the basis of the prepared maps, and through cartographic and statistical methods, the types of spatial distribution of populations were established. The evolution of spatial structure was carried out using the "Leksis' index". For each population the coefficient of dispersion was evaluated.
On the basis of morphological and developmental properties the number of individuals in each age stage (juvenile, vegetative, reproductive and senile) was established. This, in turn, provided a basis for the evaluation of the age structure. The measurements of shoot height, the number of modules and rosettes and the diameter of tussocks helped to evaluate the size structure of the individuals in a population. Numerical data acquired in field observations were processed using statistical methods (Zar 1998).

\subsection{Diversity of communities}

Diversity of the oak-hornbeam natural and anthropogenically disturbed communities was defined using 92 phytosociological records collected in the period 1987-2009 as a basis. The phytosociological record covered $500 \mathrm{~m}^{2}$ or 5 square of $100 \mathrm{~m}^{2}$ permanent study fields. The Braun-Blanquet method, commonly applied in phytosociology, was employed. According to Matuszkiewicz's (2001) a list of characteristic species, categorisation of syntaxonomic groups was performed. The names of vascular plants were given after Mirek et al. (2002) and mosses after Ochyra et al. (2003). On the basis of an average cover coefficient for each plant layer, Hult's diagram was made to show the vertical structure of the phytocoenoses.

\section{Results}

\subsection{Modification of Carex digitata life history}

The life cycle of $C$. digitata development lasts from 5 to 10 years. In the natural community, $C$. digitata individuals reach the phase of flowering and fruiting in the $4^{\text {th }}$ year of life, while in the disturbed community with domination of pine trees in the $2^{\text {nd }}$ year of life (Fig. 2). In the disturbed community, the pre-reproductive period is shortened relative to that in the natural community as the seedling, juvenile and virginal phases are shorter:

- in the natural oak-hornbeam community individual plants remain in the seedling state until the end of the first season of growth, while in the disturbed community affected by the process of pinetization, in autumn, $20 \%$ of the seedlings reach the juvenile state in the first growing season after seed germination;

- in the natural oak-hornbeam community the early-vegetative state begins 3 years after sowing and lasts about 2 years, in the disturbed community with domination of pine trees, in the spring 2 years after germinating, individual plants will be passing through the early-vegetative state, so that by summer they reach the mature vegetative or the reproductive states. 


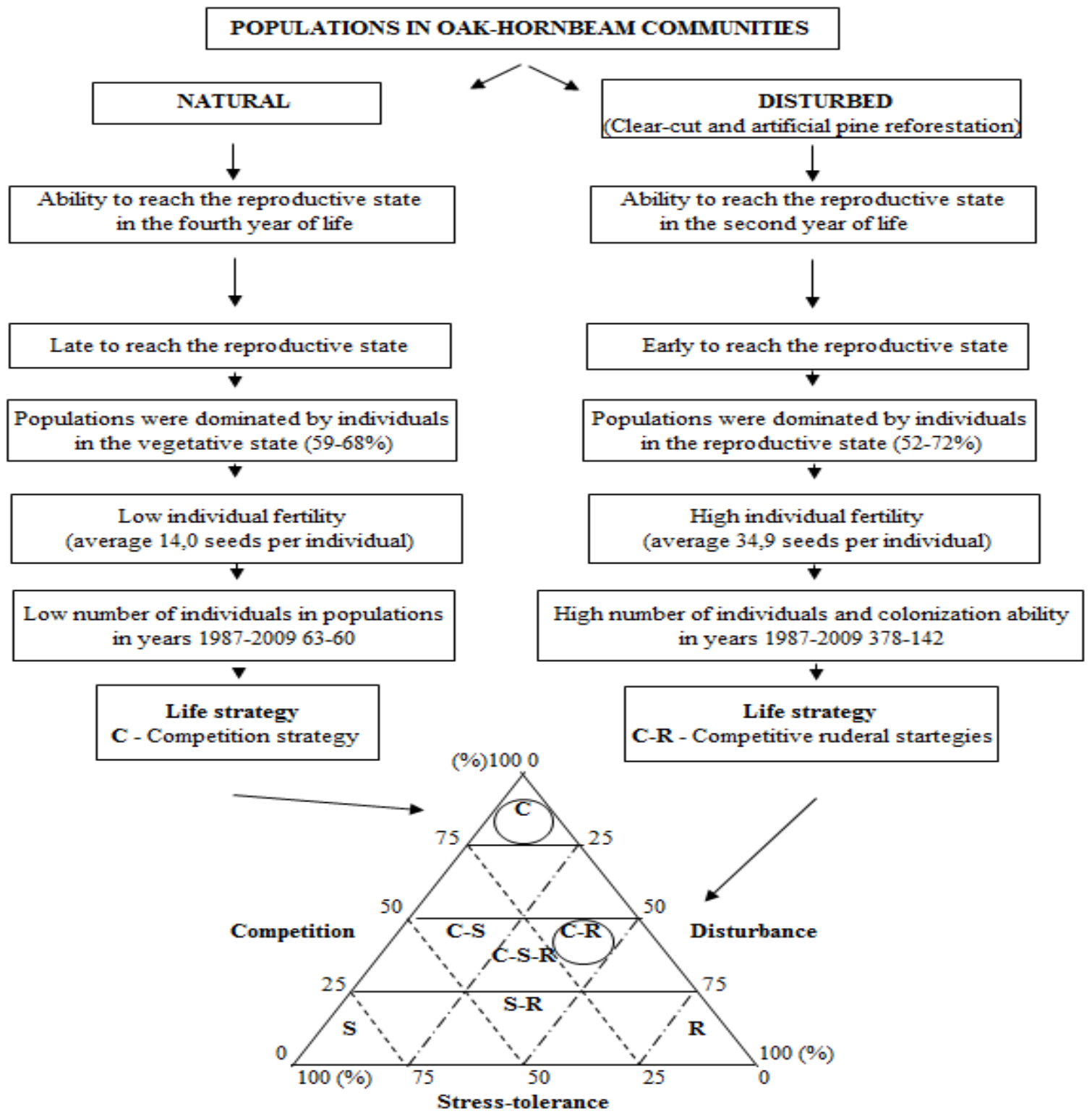

Figure 2. Modification of the Carex digitata L. life history in natural and anthropogenically disturbed oak-hornbeam communities (Source: Łaska 1996b, changed)

\subsection{Structure and dynamics} of plants population of Carex digitata

The structure and dynamics of plant populations of $C$. $d i$ gitata reflects the response of individual plants to changes in the habitat resulting from disturbing factors. Changes in life history, as well as their great plasticity have demographical consequences and affect the population dynamics. Populations of $C$. digitata in the natural and the anthropogenically disturbed communities differed in size. A larger number of populations and temporal changes were observed in the anthropogenically disturbed community than in the natural oak-hornbeam community.

\subsection{Changes in spatial organisation of Carex digitata}

Spatial organisation of populations in the natural oak-hornbeam community was different from that in the anthropogenically disturbed community (Fig. 3). In the natural oak-hornbeam community, the density of individual plants in the population was low, changed slightly over the years 
a)

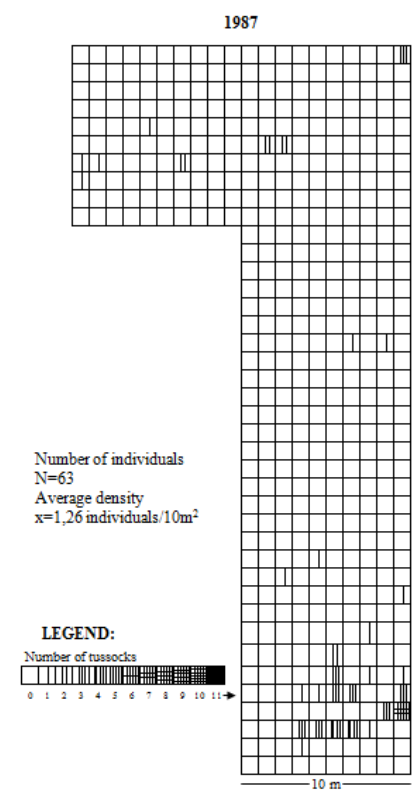

b)

1987

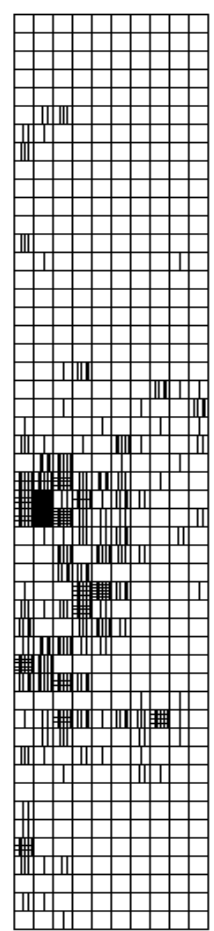

$\underset{N=378}{\text { Number of individuals }}$

$\underset{x}{\mathrm{~A}=}=7,56$ individuals $/ 10 \mathrm{~m}$

\section{Natural community}

1998

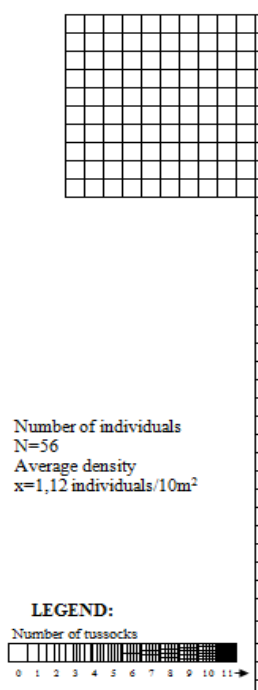

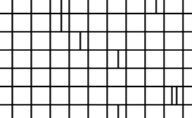

$+\frac{1}{1+1}$

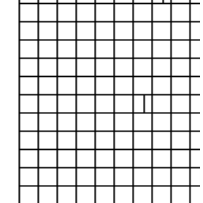

Ð

$\mathrm{N}=60$

Average density

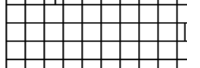

$\mathrm{x}=1,2$ individuals $/ 10 \mathrm{~m}^{2}$
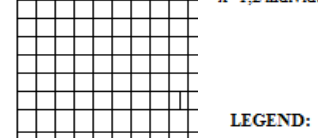

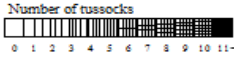

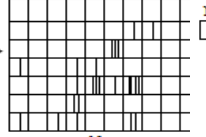

\section{LEGEND:}

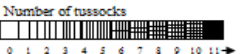

2009

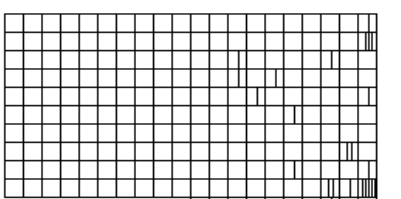

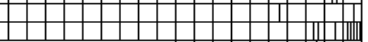

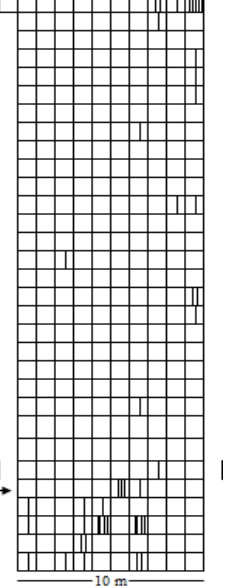

Disturbed community

1998
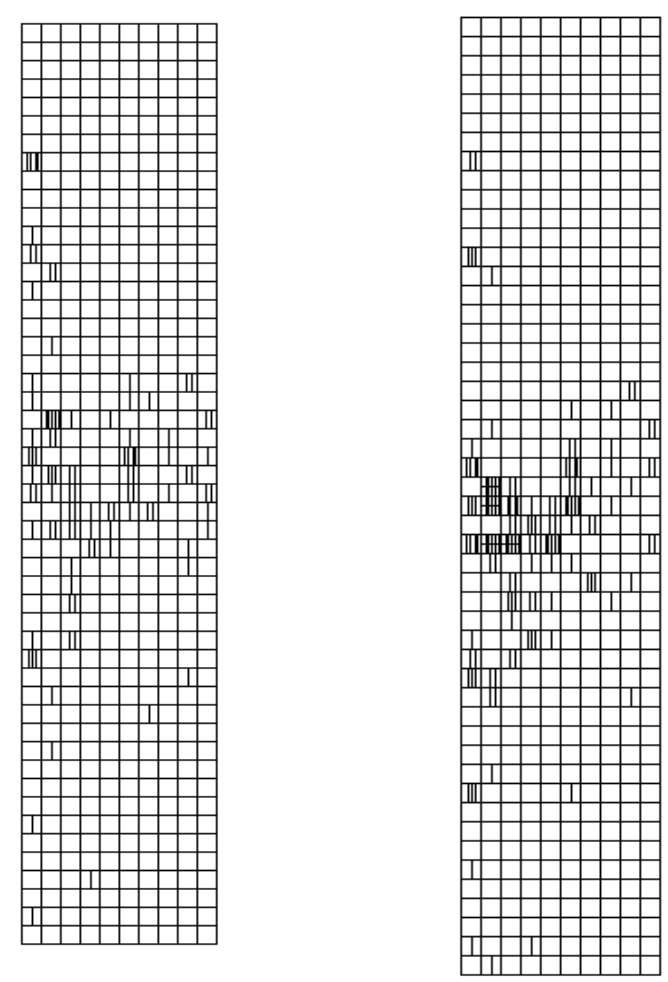

$\underset{N=100}{N}$ Number of individual

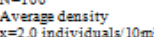

$\mathrm{N}=142 \mathrm{mber}$ of individuals

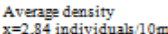

Figure 3. Changes in the spatial structure of Carex digitata populations determined in the period 1987-2009: a) in the natural community, b) in the disturbed community 
1987-2009 and amounted to about 1 individual per $10 \mathrm{~m}^{2}$. In the natural oak-hornbeam community the number of tussocks in aggregations and the area they covered was low and changed insignificantly in the 23-year research cycle. The area of an aggregation ranges on average, from about $2 \mathrm{~m}^{2}$ to $6 \mathrm{~m}^{2}$. The maximum number of individuals in an aggregation was 5 to 27 tussocks, while in the aggregation area of $1 \mathrm{~m}^{2}$ the maximum number of tussocks observed ranged from 4 to 7 . In the natural oak-hornbeam community the aggregations of individual plants were at noticeable distances from one another (Fig. 3). The type of spatial structure of this population resembles the distribution type as dispersed-aggregated.

In the anthropogenically disturbed community, the spatial structure of $C$. digitata population reached different properties (Fig. 3). The density of individual plants in the population was high. In 1987-2009 it changed significantly, decreasing from about 7.6 to 2.8 individuals per $10 \mathrm{~m}^{2}$. In 1987, the number of tussocks in aggregations and the area they covered were high. In the 23-year of study these values significantly decreased, because in the disturbed community the process of regeneration of the vegetation is observed. The area of an aggregation ranged on average from $7-14 \mathrm{~m}^{2}$ to $2.6-4.4 \mathrm{~m}^{2}$. The maximum number of individuals in an aggregation decreased from 190-204 to 10-31 tussocks, while in the area of $1 \mathrm{~m}^{2}$ of an aggregation the maximum number of tussocks observed decreased from 11-26 to 6-9. In the population studied the variation in the spatial organisation over the years 1987-2009 was found quite significant. The distribution of individuals in space changed from corn-aggregate to dispersed-aggregate (Fig. 3). A change in the spatial organisation in the disturbed community may indicate a regression of the $C$. digitata population.

\subsection{Age structure of Carex digitata populations}

The development of the $C$. digitata populations in the communities studied revealed a significant variation in the proportions of individual plants at different age stages (Fig. 4). In the years 1987-2009, the following two types of age distribution and their characteristic changes were observed:

- domination of individuals in the vegetative stage or, at some stage in the development of the population, an increase in the number of individuals in the reproductive stage; the phenomena occurred in the population from the natural oak-hornbeam community;

- domination of individuals in the reproductive stage, but rapid changes in proportions of individuals at different age stages took place: an increase in the number of individuals in the vegetative stage was accompanied by a decrease in the number of individuals in the reproductive stage; these dynamical changes occurred in the population from the anthropogenically disturbed community.

The variation in the age structure described above in the sedge populations studied was reflected in the shape of the age structure pyramids (Fig. 4). In the population from the natural oak-hornbeam community the age structure appeared graphically as a flat-pyramid (1989, 1990, $1993,2000,2003,2006)$ and an increase in the number of individuals in the vegetative stage was observed (from $59 \%$ to $68 \%$ ). In the population from the anthropogenically disturbed community, the age structure appeared graphically as an inverted pyramid (1987, 1989, 1990, 1991, 1994, $1996,1997,2003,2006,2009)$ and an increase in the number of individuals in the reproductive stage (from $52 \%$ to $72 \%$ ) was observed.

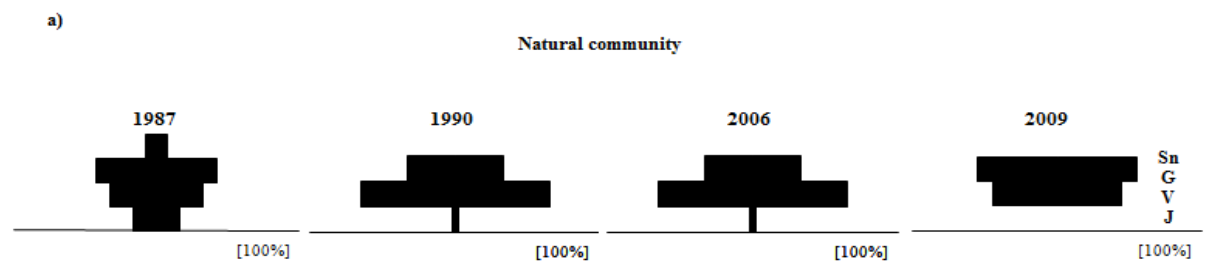

b)

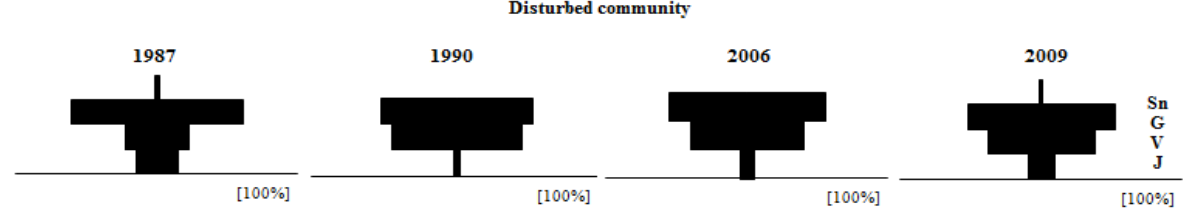

Figure 4. Changes in the age structure of Carex digitata populations determined in the period 1987- 2009: a) in the natural community, b) in the disturbed community. Individuals in age state: J - juvenile, V - vegetative, G - reproductive, $\mathrm{Sn}$ - senile 


\subsection{Size structure of individuals and temporal changes}

The study revealed statistically significant differences in the height of individual plants and in the structure of the sedge tussocks in the populations from the natural and the anthropogenically disturbed communities (Figs. 5-6).

At the beginning of the observations, in 1987, individuals in the population from the anthropogenically disturbed oak-hornbeam community reached bigger sizes of tussocks (average height $-20.0 \mathrm{~cm}$, tussock diameter $-8.8 \mathrm{~cm}$, average number of modules -1.83 ) than those from the natural oak-hornbeam community (average height $-15.1 \mathrm{~cm}$, tussock diameter $-4.3 \mathrm{~cm}$, average number of modules 1.73) (Figs. 5-6). The height of the individuals in the natural oak-hornbeam community, in the years 1987-2009 increased, however only slightly, their average height ranged from $15.1 \mathrm{~cm}$ to $20.5 \mathrm{~cm}$ (Fig. 5). The maximum height of individual plants reached from 26 to $37 \mathrm{~cm}$. The tussock consisted of a maximum of 3 to 14 modules and 7 to 20 rosettes. In the natural oak-hornbeam community, changes in the number of modules in the structure of sedge tussocks were statistically insignificant (from 1.73 to 1.92 modules in a tussock) and the 1-module individuals were dominant (Figs. 5-6) during the 23-year research cycle (1987-2009). In 1987-2009, greater changes in the structure of the sedge tussocks and statistically significant differences were reported in the decreasing number of rosettes (from 5.4 to 3.7 rosette in a tussock). This supposedly determined the decrease in the sedge tussock diameter in the period of the study, from $4.3 \mathrm{~cm}$ to $3.8 \mathrm{~cm}$.

In the population from the anthropogenically disturbed community the maximum height of individual plants reached from 29 to $42 \mathrm{~cm}$. The tussock consisted of a maximum of 3 to 12 modules and 5 to 21 rosettes. In the community affected by pinetization, individual plants formed tussocks of diameters ranging $7.6-8.8 \mathrm{~cm}$, which
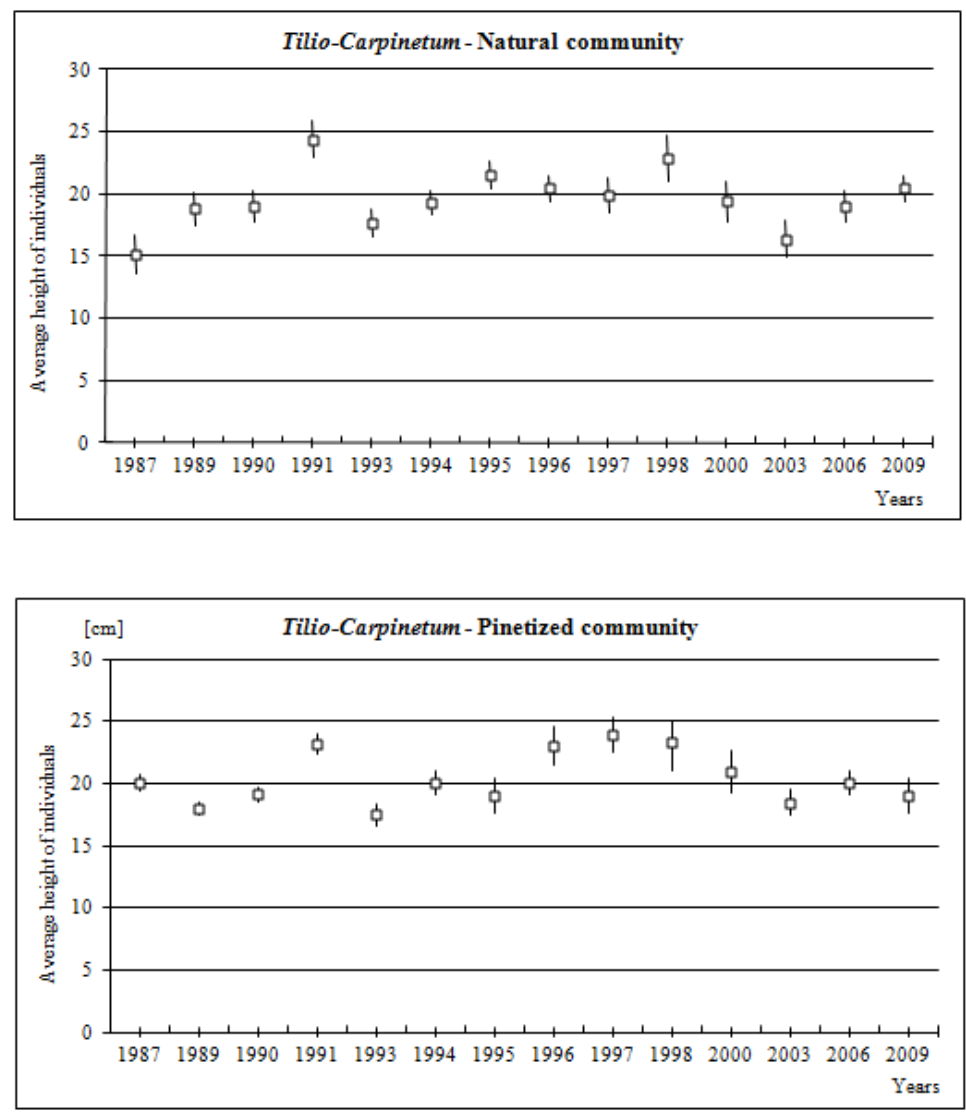

Ф $-x \pm L$ - Average height of individuals + confidence limit

Figure 5. Change in the individuals height of Carex digitata populations determined in the period 1987-2009 in different communities in the Knyszyńska Forest 

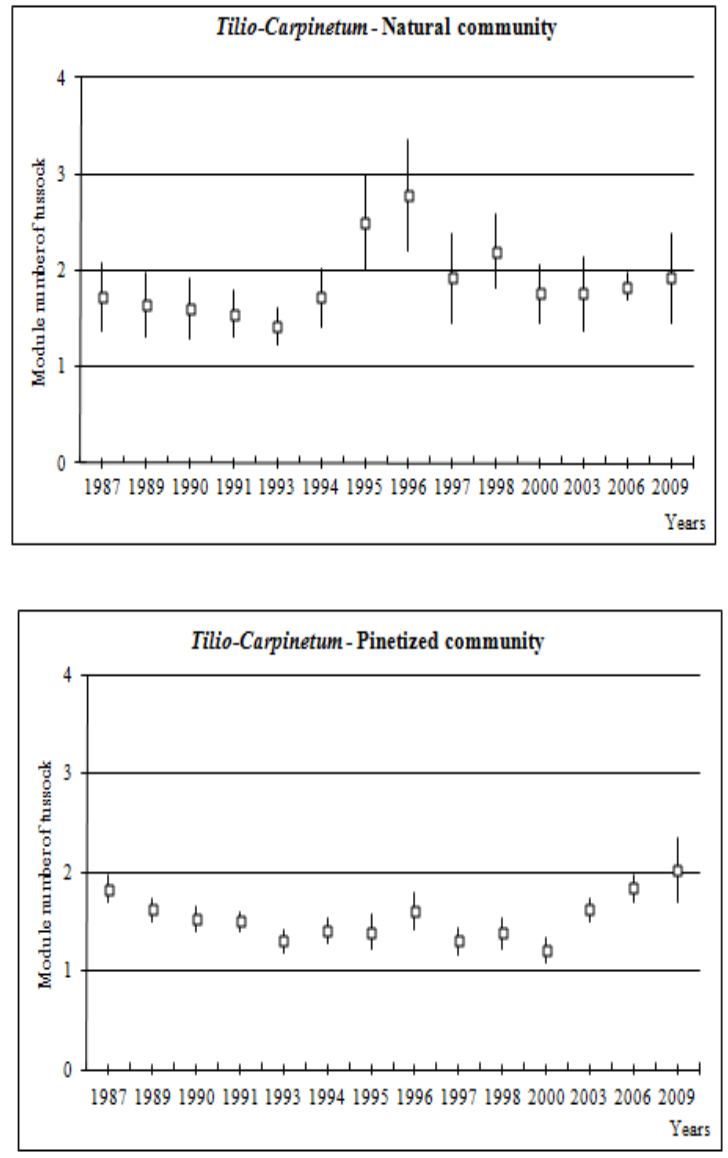

† $-x \pm L$ - Average module number in tussock + confidence limit
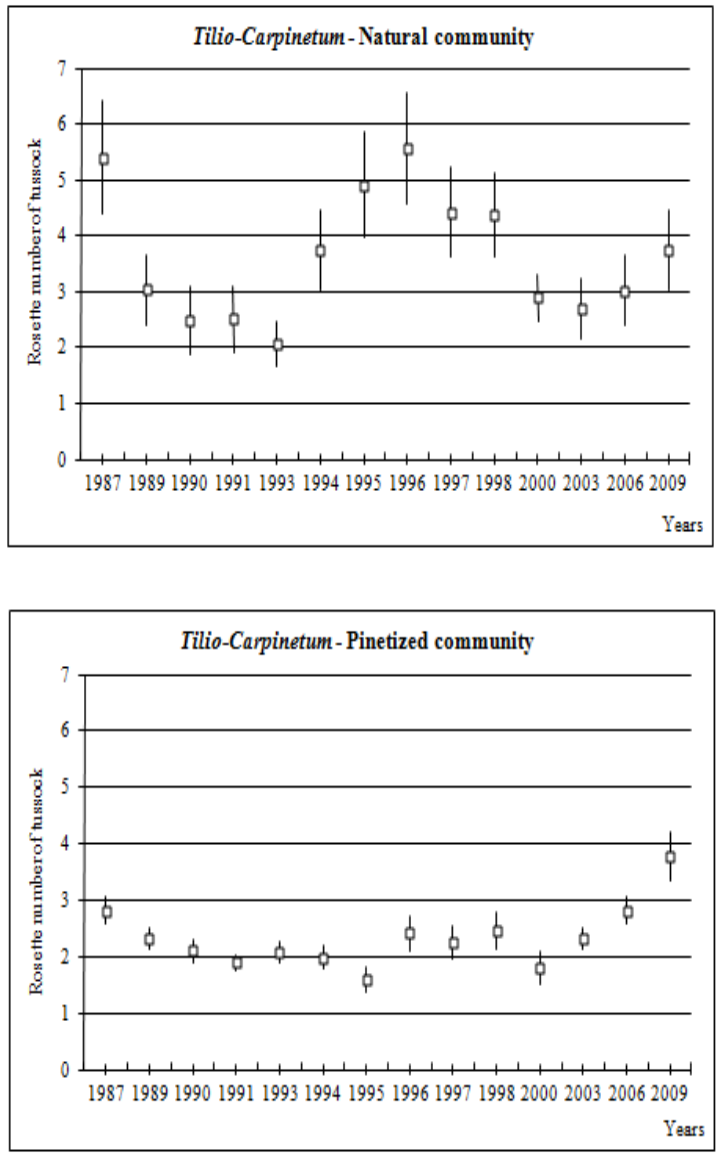

† $-x \pm L$ - Average rosette number in tussock + confidence limit

Figure 6. Change in the structure of Carex digitata tussock determined in the period 1987-2009 in the communities studied in the Knyszyńska Forest

is twice as much as those from the natural oak-hornbeam community. In the population from the anthropogenically disturbed community the domination of individuals in the reproductive phase determined a smaller range of variation in the average values of the tussock's features analysed. However, in the 23-year study (1987-2009), changes in the average height of individuals (from $20.0 \mathrm{~cm}$ to $19.1 \mathrm{~cm}$ ), the number of modules (from 1.83 to 2.02 modules in a tussock), and the number of rosettes (from 2.8 to 3.8 ) were statistically significant (Figs. 5-6). It is supposedly related to a decrease in the population abundance in recent years and the process of regeneration of the vegetation in this community.

\subsection{Dynamics of population Carex digitata}

Observations of the life histories of tagged individuals in permanent sites indicated changes in the number of in- dividuals in the populations over the years 1987-2009. Changes in the number of individuals in a particular age stage were also observed. The results suggest the following pattern of changes in the population abundances in the perennial life cycle of $C$. digitata (Fig. 7):

- the number of individuals remains at a relatively stable level, or changes slightly in the population from the natural oak-hornbeam community;

- in the anthropogenically disturbed community a decline in the population abundance is noted.

At the beginning of the observation period (1987), in an area of $500 \mathrm{~m}^{2}$ a greater number of individual plants in the population was observed in the anthropogenically disturbed (379 individuals) than in the natural oak-hornbeam community (63 individuals) (Fig. 3). After 23 years (2009), in the natural oak-hornbeam community, the number of populations remained relatively stable. The number of individuals in this population changed, in an oscillatory 

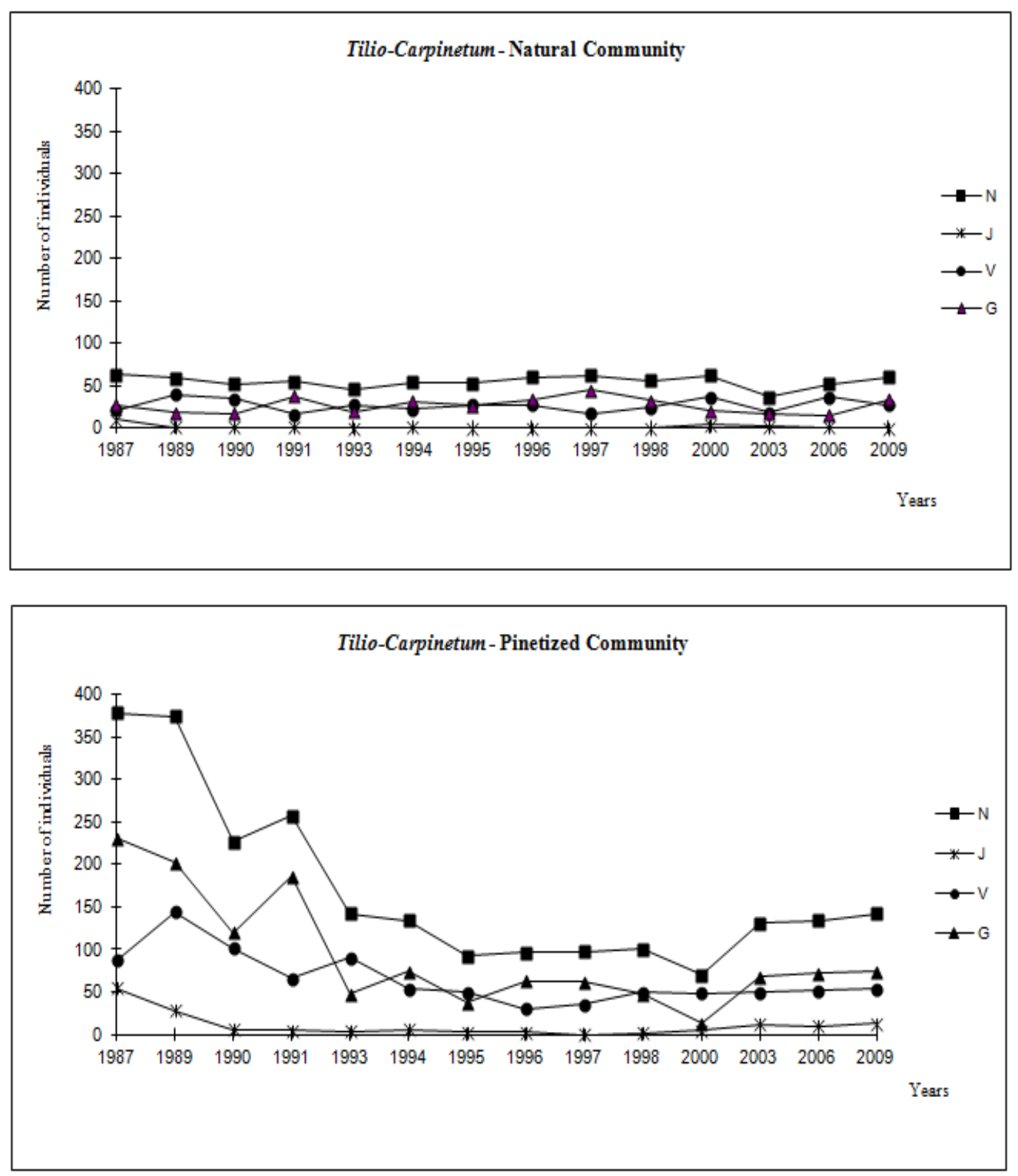

Figure 7. Change of population number of Carex digitata and change of individual numbers in particular age state in the period 1987-2009: a) in the natural community, b) in the disturbed community. Change of numbers: $\mathrm{N}$ - Carex digitata populations, $\mathrm{J}$ - individuals in juvenile phase, $\mathrm{V}$ - individuals in vegetative phase, $\mathrm{G}$ - individuals in reproductive phase

manner, from 63 to 60 individual plants (Fig. 7). The population in the natural oak-hornbeam community remained relatively constant, as new plants replaced dying ones in a roughly equal number. A relative dynamic equilibrium in the population abundance was a response to the relative stability and durability of the natural oak-hornbeam phytocoenosis.

After 23 years (1987-2009), the population in the anthropogenically disturbed community declined (from
378 to 142 individuals) (Fig. 7), as the number of dying plants was higher than that of new plants. Changes in the number of individuals may point to a decline of the population studied in the disturbed community due to rapid changes in all layers of phytocoenosis under the effect of anthropogenic activities. The modifications of features and population properties in the disturbed communities can serve as an indicator of their disturbance. 


\subsection{Discussion and Conclusion}

The results of the study reported unequivocally point to interrelations between variation in the life history traits of C. digitata in the natural and anthropogenically disturbed communities and structural features and dynamics of the population. C. digitata response to disturbance factors can be explained by a different strategy of life (Fig. 2), which through differentiation of morphological-developmental properties of individuals determines variation in the population features. This is reflected in different spatial organisation of the population, a different age structure, size structure and other mechanisms regulating the population abundance. Population dynamics significantly correspond to dynamics of communities and the relations are a response of $C$. digitata population to dynamic vegetation changes in the natural habitat (fluctuation) and or imposed by anthropogenic disturbances (degeneration as a result of pinatization followed by regeneration). This implies that they are the response of the sedge population to disturbances of phytocoenotic, microclimatic, phenological and biocenotic factors.

It can be assumed that low fertility and prolonged pre-reproduction time of $C$. digitata in the natural community is a result of natural selection $\mathrm{C}$ (sensu Grime) (Fig. 2). In the natural community, being in the equilibrium phase, the most important of various factors modifying population properties, according to Grime (1988), is the competition and competitive impact of the other components of a given phytocoenosis. The sedge $C$. digitata growing in the conditions of strong competitive pressure of the richly developed ground cover of oak-hornbeam species (in spring geophytes cover $100 \%$ and in summer hemicryptophytes cover $80-100 \%$ ) uses most of its biomass and energy for development of vegetative organs. The interspecies competition limits however, the development and growth of progeny and adult individuals. Therefore, in the natural oak-hornbeam community the number of individuals in the population is low, and so are their changes over the time, the spatial distribution of the population has a character of dispersed-aggregated, and the sedge has little colonisation abilities. There is low density of individuals per unit area and within agglomerations, agglomeration area is small and the number of tussocks in agglomerations is low. Individuals in the vegetative stage dominate in the population. At the beginning of their growth they develop vegetative organs just to survive in the phytocoenosis and when they reach this stage, they are in the vegetative stage to reach the phase of flowering and fruit bearing at the age of 4 (Laska 1996a). Durability of pre-reproductive period may be used as an evaluation criterion to estimate a degree of "competitive pressure" on the sedge individuals from the part of other components of a given phytocoenosis (Howard \& Gold- berg 2001; Bornhofen et al. 2011). However, not all individuals of $C$. digitata flower and bear fruit. It has been found that some sedge individuals at the age of 4 do not form reproductive shoots and during subsequent seasons they increase the number of modules and rosettes and the height of shoots. They also develop underground organs (Łaska 1996a). These are important features of vegetative propagation, however $C$. digitata does not reproduce vegetatively but only through seeds (Nowikov 1967; Fomićeva 1977). A low number of individuals in the population and its changes over time in the form of small fluctuations and a low efficiency of generative reproduction in the natural oak-hornbeam communities can be determined by phytocoenotic relations that restrict the available space and the number of safe germination sites (Harper 1981; Silvertown 1981; Eriksson \& Ehrlén 1992). In the habitat of compact and rich ground cover of the natural oak-hornbeam communities, the number of such safe sites is limited and the covering of the upper layer of soil with permanent underground organs of geophytes and hemicryptophytes leaves little opportunities for the sedge seeds to germinate. Germination of $C$. digitata seeds takes place under the ground (hypogeic mode) (Nowikov 1967). Therefore, their deposition depth in the soil plays an important role in the further development and growth of the individuals. In the oak-hornbeam natural communities, whose changes are fluctuational in character, the most important factor determining the structure and dynamic of populations of the sedge $C$. digitata is the competition of the other components of the oak-hornbeam ground cover. The competition pressure determines prospective reproduction abilities of the sedge, the size and abundance of the population (Wilson \& Keddy 1986; Menge \& Sutherland 1987; Tilman 1988; Pugliese \& Kozłowski 1990; Schmid 1990; Falińska 1998a; Grime 2001; Westoby et al. 2002).

Different structure and dynamic of population changes were established over the years 1987-2009 in the anthropogenically disturbed oak-hornbeam community. In the disturbed community $C$. digitata individuals are characterised by a shortened pre-reproductive period and reach the generative phase earlier which enables them to adapt to environmental changes caused by the disturbance quicker. In the population growing in disturbed areas, the fraction of flowering and fruit bearing individuals dominates, plants are characterised by high fertility, and seeds by great germination ability (Łaska 1996a, 1998). The effectiveness of reproduction may be a result of adaptation to environmental changes induced by man's activity, i.e. during colonisation processes, C-R strategies (Fig. 2). C. digitata belongs to the species appearing in the first phases of colonisation in deforestated areas. In the first year after deforestation it formed an abundant population (Laska 2006). The individuals produced a large number of generative shoots and seeds. These characteristics determine the priority of 
C. digitata in the process of colonisation of disturbed areas. In the disturbed community, the best strategy is to accumulate the maximum biomass and energy for reproduction (Urbanska 1984, 1989; Bazzaz et al. 1987; Grime 1988; Lovett Doust 1989; Kozłowski 1992; Reznicek 1992; Ashman 1994; Acosta et al. 1997; Grime 2001; López et al. 2001). Individuals reach the reproductive stage early, and liberation from the pressure of competitors makes $C$. digitata to show enormous capabilities of development. In this population, the individuals in the reproductive stage are dominant. In a short period of time the tussocks produce a large number of living and reproductive shoots leading to high reproduction abilities and large population abundance. In the disturbed oak-hornbeam community spatial distribution of the population is of corn-aggregate. There is a high density of individuals per $1 \mathrm{~m}^{2}$, high number of agglomerations and high density of individuals in agglomerations. The areas of agglomerations are twice as big as in the natural oak-hornbeam communities. The population abundance and the surface coverage determine a more important role of the sedge in the ground cover of the disturbed oak-hornbeam community than in its natural form. In the course of pinetization of oak-hornbeam phytocoenosis, significant changes occur in the soil microflora, kind of litter and the soil pH into more acidic (Laska 1997, 2004, 2006) as a result of intensive production and fall of conifer needles. Because of these changes, in the disturbed communities the ground cover is poor $(40 \%)$ with a significant contribution of acidofile species, including acidofile moss cover (20\%) and the ground litter is different as it contains mainly pine needles. These changes in comparison with the natural oak-hornbeam community (considerable richness of the herbal cover, deciduous litter which makes it difficult for the seeds to germinate), can also largely determine the size and abundance of the sedge populations in the disturbed oak-hornbeam community. This indicates the effective renewal of $C$. digitata populations needing a high diversity of habitats. The seed germination and seedling survival in the population is largely dependent on their protection by moss. Moss layer protects $C$. digitata against sudden fluctuations in temperature at the ground level, while its water-retention capacity can positively regulate the moisture content. This has also been proved in the earlier studies, where in the coniferous forest communities with richness of the moss cover $(80 \%)$, the number of individuals in the populations was the highest (2086-2672 individuals per $500 \mathrm{~m}^{2}$ ) (Łaska 1996b).

The diversity in the environmental conditions contributes to the situation in which each population (in natural and disturbed community) develops its own life strategy to ensure the production of new plants (Taylor et al. 1990; Yong 1995; Grime 2001; Westoby et al. 2002; Bornhofen et al. 2011). Each strategy can be considered successful as population following it survive and renew themselves. It points to the effectiveness of other mechanisms modified by evolution by which individuals of the same species ensure reproductive success in different ways. It seems that one of the advantages resulting from the choice of a particular life strategy is the shortening of the life cycle of individuals in disturbed community; in this way individual plants can quickly adapt to changes in the environmental conditions. The rate and intensity of changes in the population properties are determined mainly by phenotypical variation in the life history traits (Grime et al. 1986; Bernard 1990; Stearns 1992; Charnov 1997; Huber et al. 1999). Therefore, more often the role of species in the formation and disappearance of specific floristic compositions is related to different life strategies (Grime 1988, 2001; Taylor et al. 1990; Łaska 1996a, b, 1998; Falińska 1997, 1998b; Willis \& McElwain 2002; Mustard et al. 2003).

\section{References}

Acosta F. J., Delgado J. A., López F. \& Serrano J., 1997, Functional features and ontogenetic changes in reproductive allocation and partitioning strategies of plant modules, Plant Ecology 132: 71-76.

Ashman T. L., 1994, A dynamic perspective on the physiological cost of reproduction in plants, Am. Nat. 144: 300-316.

Bornholfen S., Barot S. \& Lattaud C., 2011, The evolution of CSR life strategies in a plant model with explicit physiology and architecture, Ecol. Modell. 222: 1-10.

Bazzaz F. A., Chiariello N. R., Coley P. D. \& Pitelka L. F., 1987, Allocating resources to reproduction and defense, BioScience 37: 58-67.

Bernard J. M., 1990, Life history and vegetative reproduction in Carex, Can. J. Bot. 68: 1441-1448.

Charnov E. L., 1997, Trade-off-invariation rule for evolutionary stable life histories, Nature 387: 393-394.

Chapin F., Autumn K. \& Pugnaire F., 1993, Evolution of siutes of traits in response to environmental stress, Am. Nat. 142: 78-92.

Craine J. M., Froehle J., Tilman D. G., Wedin D. A. \& Chapin I. F. S., 2001, The relationships among root and leaf traits of 76 grassland species and relative abundance along fertility and disturbance gradients, Oikos 93: 274-285.

Ellenberg H., 1974, Zeigerwerte der Gefäßpflanzen Mitteleuropas, Scripta Geobotanica 9: 1-122.

Eriksson O. \& Ehrlén J., 1992, Seed and microsite limitation of recruitment in plant populations, Oecologia 91: 360-364.

Falińska K., 1997, Life history variation in Cirsium palustre and its consequences for the population demography in vegetation succession, Acta Soc. Bot. Pol. 66: 207-220. 
Falińska K., 1998a, Plant population biology and vegetation processes, Polish Academy of Sciences, Kraków.

Falińska K., 1998b, Pattern of life history, [in:] K. Falińska (ed.), Plant population biology and vegetation processes, Polish Academy of Sciences, Kraków: 44-64.

Falster D. S. \& Westoby M., 2003, Plant height and evolutionary games, Trends in Ecology and Evolution 18: 337-343.

Fomičeva N. I., 1977, Izmienienije spectra pocek v zavisimosti ot vozrastnovo sostajanija osoki palcatoj, Biologiczeskije Nauki 4: 97-102.

Grime J. P., 1979, Plant strategies and vegetation processes, John Wiley \& Sons, Chichester.

Grime J. P., 1987, Dominant and subordinate components of plant communities: implications, stability and diversity, [in:] A. J. Gray, M. J. Crawley, P. J. Edwards (eds.), Colonization, succession and stability, Blackwell, Oxford: 413-428.

Grime J. P., 1988, The C-S-R model of primary plant strategies - origins, implications and tests, [in:] L. D. Gottlieb, S. K. Jain (eds.), Plant evolutionary biology, Chapman, Hall, London: 371-393.

Grime J. P., 2001, Plant strategies, vegetation processes, and ecosystem properties, Wiley, Chichester.

Grime J. P., Crick J. C. \& Rincon J. E., 1986, The ecological significance of plasticity, [in:] D. H. Jennings, A. J. Trewaves (eds.), Plasticity in plants, Company Biologists, Cambridge: 5-29.

Harper J. L., 1981, The concept of population in modular organisms, [in:] R. May (ed.), Theoretical Ecology, Principles and Applications, Blackwell Scientific Publications, Oxford: 53-77.

Howard T. G. \& Goldberg D. E., 2001, Competitive response hierarchies for germination, growth, and survival and their influence on abundance, Ecology 82: 979-990.

Huber H., Lukács S. \& Watson M. A., 1999, Spatial structure of stoloniferous herbs: an interplay between structural blue-print, ontogeny and phenotypic plasticity, Plant Ecology 141: 107-115.

Kozłowski J., 1992, Optimal allocation of resources to growth and reproduction: implications for age and size at maturity, Trends in Ecology and Evolution 7: 15-19.

Lehsten V. \& Kleyer M., 2007, Turnover of plant trait hierarchies in simulated community assembly in response to fertility and disturbance, Eco. Modell. 203: 270-278.

Loeuille N. \& Leibold M. A., 2008, Ecological consequences of evolution in plant defenses in a metacommunity, Theoretical Population Biology 74: 34-45.

López F., Fungairiňo S., De las Heras P., Serrano J. \& Acosta F., 2001, Age changes in the vegetative vs. reproductive allocation by module demographic strategies in a perennial plant, Plant Ecology 157: 13-21.
Lovett Doust J., 1989, Plant reproductive strategies and resources allocation, Trends in Ecology and Evolution 4: $230-234$.

Łaska G., 1996a, Changes in the life history of Carex digitata in disturbed woodland communities. I. Life history, Frag. Flor. Geobot. 41: 419-445.

Łaska G., 1996b, Changes in the life history of Carex digitata in disturbed woodland communities. II. Demography of Carex digitata, Fragmenta Floristica et Geobotanica 41: 447-473.

Łaska G., 1997, Degenerative forms and phases of secondary hornbeam communities, Ekologia Polska 45: 461-493.

Łaska G., 1998, Carex digitata in the process of degeneration and regeneration of forest communities, [in:] K. Falińska (ed.), Plant population biology and vegetation processes, Polish Academy of Sciences, Kraków: 133-138.

Łaska G., 2001, The Disturbance and Vegetation Dynamics: a review and an alternative framework, Plant Ecology 157: 77-99.

Łaska G., 2003, Theory of disturbance and dynamics of vegetation, Ecological Questions 3: 9-24.

Łaska G., 2004, Identification and classification of the secondary communities of the Knyszyńska Forest, Fragmenta Floristica et Geobotanica Polonica, Supplement 6: 101-120.

Łaska G., 2006, Tendencje dynamiczne zbiorowisk zastępczych w Puszczy Knyszyńskiej [Dynamic tendencies of the secondary communities in the Knyszyńska Forest], Bogucki Wydawnictwo Naukowe, Białystok-Poznań.

Matuszkiewicz W., 2001, Przewodnik do oznaczania zbiorowisk roślinnych Polski [A guide for identification of plant communities in Poland], Państwowe Wydawnictwo Naukowe, Warszawa.

MacArthur R. H., Wilson E. D., 1967, The Theory of Island Biogeography, Princeton University Press, Princeton NJ.

Menge B. A. \& Sutherland J. P., 1987, Community regulation: variation in disturbance, competition, and predation in relation to environmental stress and recruitment, Am. Nat. 130: 730-757.

Mirek Z., Piękoś-Mirkowa H., Zając A. \& Zając M., 2002, Flowering Plants and Pteridophytes of Poland. A Checklist, Polish Academy of Sciences, Kraków.

Mustard M. J., Standing D. B., Aitkenhead M. J., Robinson D. \& McDonald A. J. S., 2003, The emergence of primary strategies in evolving virtual-plant populations, Evolutionary Ecology Research 5: 1067-1081.

Nowikov W. S., 1967, Rod Carex L. vo florie Moskovskoj obłasti (voprosy biomorfołogii, anatomii, systiematiki i gieografii), Nauka, Moskwa. 
Ochyra R., Żarnowiec J. \& Bednarek-Ochyra H., 2003, Census catalogue of Polish mosses, Polish Academy of Sciences, Kraków.

Pianka E. R., 1970, On r- and K-selection, Am. Nat. 104: 592-597.

Pickett S. T. A., Kolasa J., Armesto J. J. \& Collins S. L., 1989, The ecological concept of disturbance and its expression at various hierarchical levels, Oikos 54: 129-136.

Poschlod P., Kleyer M. \& Tackenberg O., 2000, Databases on life history traits as a tool for risk assessment in plant species, Zeitschrift für Ökologie und Naturschutz 9: 3-18.

Pueyo Y., Kéfi S., Dĭaz-Sierra R., Alados C. L. \& Rietkerk M., 2010, The role of reproductive plant traits and biotic interactions in the dynamic of semi-arid plant communities, Theoretical Population Biology 78: 289-297.

Pugliese A. \& Kozłowski J., 1990, Optimal patterns of growth and reproduction for perennial plants with persisting or not persisting vegetative parts, Evolutionary Ecology 4: 75-89.

Ramenskii L. G., 1938, Introduction to the geobotanical study of complex vegetations, Selkhozgiz, Moscow.

Reznicek P., 1992, Measuring the cost of reproduction, Trends in Ecology and Evolution 7: 42-45.

Schmid B., 1990, Some ecological and evolutionary consequences of modular organization and clonal growth in plants, Evolutionary Trends in Plants 4: 25-34.

Silvertown J., 1981, Microspatial heterogeneity and seedling demography in species-rich grassland, New Phytologist 88: 117-128.

Stearns S. C., 1992, The evolution of life histories, Oxford University Press, Oxford.

Tayler T., Prentice H. C. \& Widén B., 2002, Geographic variation and dispersal history in Fennoscandian popu- lations of two forest herbs, Plant Systematics and Evolution 233: 47-64.

Taylor D. R., Aarssen L. W. \& Loehle C., 1990, On the relationship between $\mathrm{r} / \mathrm{K}$ selection and environmental carrying capacity: a new habitat templet for plant life history strategies, Oikos 58: 239-250.

Tilman D., 1988, On the meaning of competition and the mechanisms of competitive superiority, Functional Ecology 1: 304-315.

Urbanska K. M., 1984, Plant reproductive strategies, [in:] W. F. Grant (ed.), Plant biosystematics, Academic Press, Toronto: 211-228.

Urbanska K. M., 1989, Reproductive effort or reproductive offer? A revised approach to reproductive strategies of flowering plants, Botanica Helvetica 99: 49-63.

Westoby M., Falster D. S., Moles A. T., Vesk P. A. \& Wright I. J., 2002, Plant ecological strategies: some leading dimensions of variation between species, Annual Review of Ecology and Systematics 33: 125-159.

Willis K. J. \& McElwain J. C., 2002, The Evolution of Plants, University Press, Oxford: 378.

Wilson S. D. \& Keddy P. A., 1986, Species competitive ability and position along a natural stress/disturbance gradient, Ecology 67: 1236-1242.

Yong B., 1995, Evolution of life history strategy in plants, Journal of Ecology 14: 33-39.

Zar J. H., 1998, Biostatistical analysis, Prentice Hall, New Jersey.

Zarzycki K., Trzcińska-Tacik H., Różański W., Szeląg Z., Wołek J. \& Korzeniak U., 2002, Ecological indicator values of vascular plants of Poland, Polish Academy of Sciences, Kraków. 
